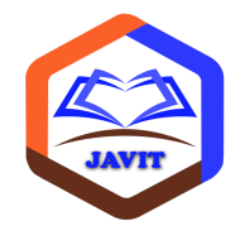

JURNAL VOKASI INFORMATIKA

(JAVIT)

Terbit online pada laman web jurnal: http://javit.ppj.unp.ac.id

DOI: https://doi.org/10.24036/javit.v2i1

ISSN: $2775-6807$

Vol. 1 No. 1 (2021) 12 - 17

\title{
Sistem Pembelajaran Berbasis Teknologi Informasi Dan Komunikasi "Studi Kasus MAS TI Canduang dengan Menggunakan Media Pembelajaran Google Classroom"
}

\author{
1, ${ }^{*}$ Adriansyah, ${ }^{2}$ Elfi Tarif \\ ${ }^{1}$ Program Studi Pendidikan Teknologi dan Kejuruan, Fakultas Teknik, Universitas Negeri Padang \\ ${ }^{1}$ Madrasyah Aliyah Swasta Tarbiyah Islamiyah Canduang \\ ${ }^{2}$ Electronic Departement, Engineering Faculty, Universitas Negeri Padang, Padang, Indonesia \\ *Coressponding author e-mail: uda_adrian@yahoo.co.id
}

\begin{abstract}
Abstrak
Pandemi covid-19 memberikan dampak pada dunia pendidikan sehingga proses belajar dilakukan secara online. Media yang paling sering digunakan dalam proses belajar secara online adalah google classrom. Penelitian ini bertujuan untuk mengetahui gambaran sistem belajar secara online dengan media google classroom yang dilakukan oleh MAS TI Canduang Sumatera Barat. Penelitian dilakukan dengan metode kualitatif deskriptif dengan instrumen penelitian wawancara online dengan menggunakan google form. Analisa data digunakan dengan tahap reduksi data, display data dan penarikan kesimpulan. Diperoleh bahwa dengan adanya media google classroom memberikan kemudahan dalam proses pembelajaran secara online, namun masih kurang efektif. Perlunya media online tambahan seperti aplikasi zoom yang dapat melakukan conference secara massal agar pembelajaran dapat berlangsung secara efektif.
\end{abstract}

Kata kunci : Proses belajar, Media, Pembelajaran Berbasis Teknologi, Google Classroom, Covid-19. 


\section{Pendahuluan}

Adanya pandemi Covid-19 merubah tata cara setiap individu baik pemerintah, masyarakat maupun seluruh elemen dalam bersosialisai, berinteraksi satu sama lain, sehingga berdampak pada ekonomi. Selain itu dunia pendidikan juga terkena dampak langsung sehingga proses belajar mengajar diubah dari tatap muka (konvensional menjadi sekolah secara online ataupun daring [1].

Menurut Handarini dan Siti dibeberap daerah, telah melakukan pembatasan wilayah terhadap warganya, masyarakat dibatasi untuk keluar masuk dalam suatu daerah, hal ini merupakan anjuran dari pemerintah setempat, sehingga pembelajaran harus dilakukan dengan daring [2].

Dalam mencegah penyebaran covid 19, organisasi kesehatan dunia (WHO) memberikan pemberitahuan untuk tidak melakukan acara-acara yang dapat menyebabkan kerumunan massa, sehingga pembelajaran yang dilakukan secara langsung atau pembelajaran yang dilakukan didalam kelas perlu ditinjau ulang pelaksanaannya. Proses pembelajaran harus diselenggarakan dengan cara yang dapat mencegah kerumunan massa, berhubungan fisik antara individu satu sama lain [3].

Untuk mengatasi permasalahan agar sekolah atau proses belajar tetap berjalan perlu dilakukan belajar secara online atau daring agar mendukung pemerintah dalam memutus rantai covid-19 [4].

Selain untuk memutus mata rantai penyebaran covid 19 dengan pembelajaran melalui media online google classroom, penggunaan belajar secara daring dapat memberikan kesempatan siswa untuk menuju aktivitas moderen dengan penggunaan aplikasi canggih, dengan tujuan siswa dapat memahami materi pembelajaran dengan interaktif, efektif, produktif dan menyenangkan. Selain itu diharapkan siswa dapat memiliki soft skill terkait penggunaan media online [5].

Pembelajaran daring ialah proses belajar denga menggunakan akses internet. Dalam proses pembelajaran dari beberapa aplikasi yang dapat digunakan seperti google classroom, zoom. Google meet, Whatsapp dan media online lainnya [4].

Dalam pembelajaran online yang dilakukan selama pandemi ini terdapat beberapa kendala yang ditemukan seperti tidak semua anak memiliki smartphone, kuota internet yang terbatas serta jaringan yang kurang mendukung.

Berdasarkan penjelasan diatas penulis ingin melakukan penelitian mengenai sistem pembelajaran dengan Media Google Classroom di MAS TI Canduang, Sumatera Barat. Dan tujuan dari penelitian ini untuk mengetahui bagaimana sistem belajar secara online dengan media google classroom yang dilakukan oleh MAS TI Canduang Sumatera Barat.

\section{Tinjauan Pustaka}

Pembelajaran daring adalah pembelajaran jarak jauh berbasis teknologi yang dapat dilakukan dengan memanfaatkan media online seperti jejaring internet. Dalam mengakses jaringan diperlukan media atau teknologi yang dapat menangkap jaringan dimana dan kapan saja, seperti komputer, smarthphone, dan lainnya [6].

Dalam pembelajaran harus ada media yang digunakan dalam prosesnya. Media adalah segala sesuatu yang dapat digunakan untuk memberi pesan dari pengirim kepada penerimanya, sehingga ide yang disampaikan sampai kepada sipenerima dengan baik pikiran, perasaan, perhatian, maupun minat siswanya dalam proses belajar [7].

Menurut Handirini, dalam proses pelaksanaan pembelajaran secara online, perlu adanya fasilityas penunjang seperti smartphone, laptop maupun sejenisnya yang dapat mengakses jaringan [5]

Dalam proses pembelajaran secara daring, ada beberapa hal penting yang harus diperhatikan, antara lain:

1. Proses pembelajaran dilakukan dengan memanfaatkan jaringan atau internet

2. Tersedianya fasilitas pendukung layanan belajar yang dimanfaatkan seperti media aplikasi online dan sejenisnya

3. Adanya layanan tutor (konsultasi) yang membantu ketika terjadi kendala atau masalah dalam belajar online

4. Harus ada lembaga yang mengelola media online dalam pembelajaran secara online

5. Sikap postif dari pengguna baik pengajar maupun siswa mengenai teknologi pembelajaran dengan menggunakan internet.

6. Dalam rancangan sistem pembelajaran melalui media harus dipelajari atau diketahui terlebih dahulu

7. Terdapat sistem untuk mengevaluasi progress serta perkembang penggunanya dalam hasil belajar

8. Mekanisme umpan balik yang dikembangkan oleh lembaga penyelenggara atau pengelola $^{[19]}$

Berdasarkan penjelasa diatas, dapat disimpulkan bahwa pada pembelajaran online, perlu diperhatikan:

1. Kegiatan yang dilakukan membutuhkan akses internet

2. Harus ada media pembelajarannya seperti aplikasi google classroom

3. Memiliki fasilitas seperti smartphone dan sejenisnya yang dapat mengakses internet

4. Perlunya pengetahuan mengenai media yang digunakan

5. Didalam media online harus ada hasil evaluasi belajar 
Dalam pembelajaran online tentu ada fungsinya , dapat dilihat sebagai berikut:

1. Sebagai suplemen (tambahan)

Dikatakan sebagai suplemen dikarenakan siswa memiliki kebebasan untuk memilihatau tidak dalam menggunakan media online sebagai media belajar)

2. Komplemen (pelengkap)

Fungsi pelengkap jika materi yang digunakan untuk melengkapi materi pembelajaran yang dilakukan oleh siswanya.

3. Susbtitusi (Pengganti)

Jika dalam pembelajaran offline atau tatap muka tidak dapat dijalankan karena sesuatu hal, maka belajar online dapat dijadikan sebagai media penggantinya [8].

Berdasarkan dari ketiga fungsi media online diatas, dapat disimpulkan bahwa pembelajaran secara daring merupakan fungsi substitusi atau penggantti

Dimasa pandemi covid-19, proses belajar dan mengajar harus dilakukan secara daring. Hal ini untuk memutus mata rantai penyebaran virus corona, sesuai dengan arahan pemerintah. Dalam pembelajaran secara daring, maka perlu adanya media berupa media online yang mendukung dalam proses belajar secara daring.

Media pembelajaran online merupakan media yang dapat digunakan oleh pengguna yang dilengkapi dengan kontrol sehingga pengguna dapat menggunakannya secara mudah [7].

Dalam pembelajaran secara daring, ada beberapa media online yang dapat digunakan seperti google classroom, whatsaap, zoom, google meet.

Google Classroom adalah aplikasi media online yang mampu menyediakan kelas untuk dapat belajar dengan fasilitas seperti pendistribusian tugas, meng-upload tugas dan menilai tugas yang sudah dikerjakan oleh siswa [5].

Google classroom merupakan salah satu media untuk pembelajaran online dan merupakan aplikasi dari pihak goole.inc. Fitur yang terdapat didalam google classroom seperti halaman utama yang dapat menampilkan kelas serta tugas penggunanya. Dalam proses belajar mengajar perlu terlebih dahulu guru/ dosen untuk membuat atau men-create kelas, matakuliah atau matapelajaran dan kemudian alamat atau link kelas dibagikan agar siswa dapat masuk kedalam kelas. Dalam penggunaan aplikasi google classroom terdapat fitur seperti pembuatan pertanyaan, daftar hadir dan pembuatan topik, dengan ini guru akan mudah untuk mengembangkan materi didalam kelas [4].

Google classroom dapat mempermudah siswa dengan dalam hal interaksi belajar online. Dalam aplikasi ini dapat berfungsi sebagai penyalur eksplorasi baik gagasan ide maupun ilmu dari guru kesiswa. Dengan adanya belajar menggunakan google classroom, waktu yang fleksibel mempermudah guru dan siswa dalam melakukan proses belajar mengajar, seperti diskusi, memberikan tugas secara online [5].

Berikut cara penggunaan aplikasi google classroom sebagai berikut:

1. Tampilan awal google classroom klik get started untuk memulai

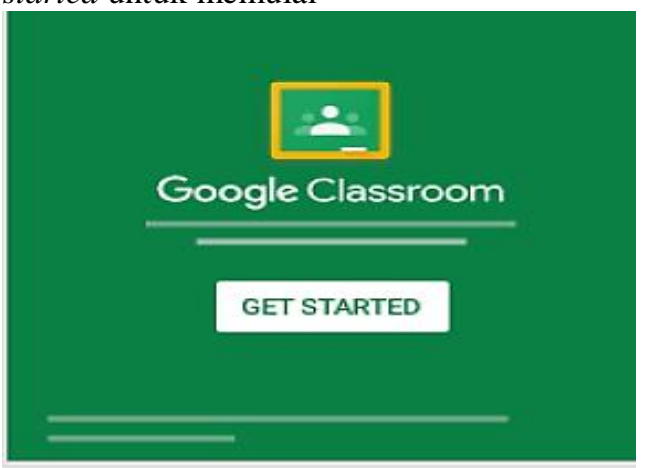

Gambar 1. Tampilan Awal

2. Kemudian siapkan akun dan klik lanjutkan

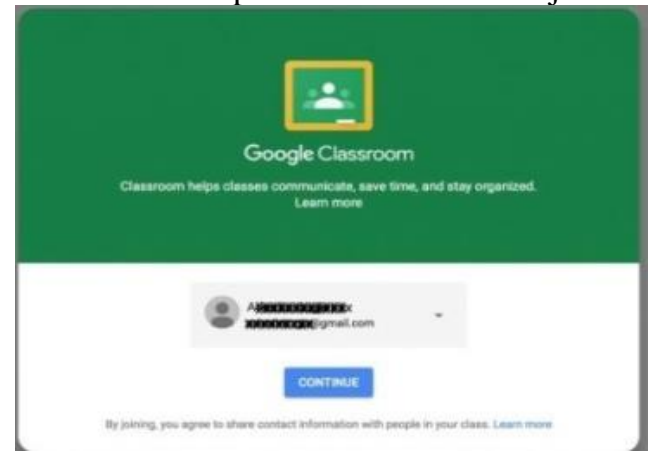

Gambar 2. Tampilan Login

3. Maka akan muncul daftar kelas, dan jika ingin membuat kelas klik create class

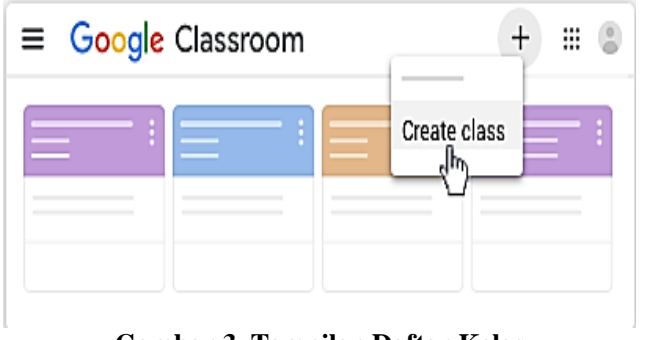

Gambar 3. Tampilan Daftar Kelas

4. Jika sudah terdaptar dikelas, maka tampilan nya sebagai berikut. Jika ingin melakukan upload dokumen atau file tugas dapat diklik menu upload 


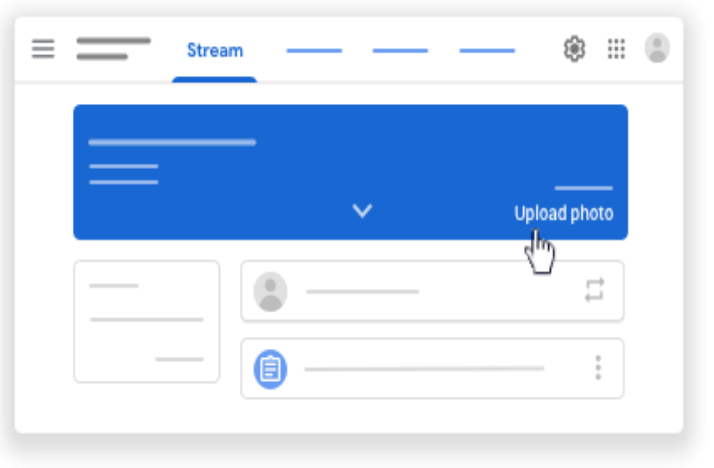

Gambar 4. Tampilan Dalam Menu Kelas

Menurut penelitian yang dilakukan oleh Wicaksono dan Putri bahwa dengan adanya penyelanggaraan google classroom di sekolah dasar dengan menggabungkan pembelajaran konvensioanal dan dengan belajar online siswa membuat siswa merasa nyaman dan aktif dalam mengonstruksi pengetahuannya. Selain itu perlu diperhatikan agar siswa diberi pelatihan penggunaan media google classroom agar proses belajar dan mengajar dapat berjalan baik [9].

\section{Metode Penelitian}

Penelitian dilakukan dengan metode kualitatif deskriptif untuk mengetahui gambaran sistem pembelajaran online dengan media google classroom di MAS TI Canduang, Sumater Barat.

Penelitian kualitatif merupakan metode yang digunakan untuk mengetahui suatu fenomena seperti perilaku, pendapat, suatu tindakan, yang dialamai oleh subjek yang akan diteliti. Metode kualitatif dalam penyajiannya dalam bentuk deskripsi kata kata [10].

Didalam penelitian ini menggunakan desain deskriptif. Desain ini digunakan untuk memperoleh jawab atas pertanyaan tentang siapa, apa, kapan, dimana, dan bagaimana keterkaitan dengan penelitian tertentu [11].

Dalam penelitian ini data diperoleh dari angket wawancara secara online dengan link format google form dikirim ke siswa.. Populasi dalam penelitian ini adalah seluruh siswa/i MAS TI Canduang Sumatera Barat. Sampel yang digunakan ialah siswa/i kelas XII MAS TI Canduang, Sumatera Barat. Analisis data dilakukan dengan melakukan reduksi data, display data, serta penarikan kesimpulan (Miles dan Huberman, 1994). Berikut tahapan analisis data dapat dilihat pada gambar 5 .

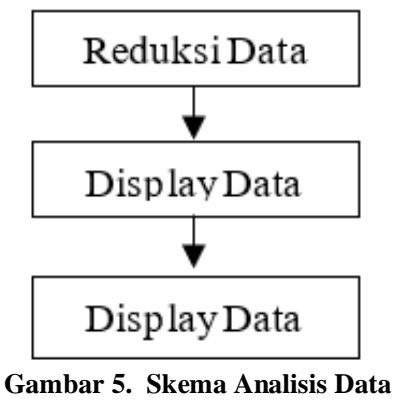

Reduksi data merupakan proses pemilihan data yang diperoleh sesuai dengan kepentingan penelitian dengan menyederhanakannya. Setelah dilakukan reduksi data dilakukan penyajian data yaitu menyajikan data yang diperoleh dalam penelitian dalam bentuk uraian, suatu bagan atau flowsheet dan sejenisnya. Dengan display data dapat memudahkan peneliti untuk memahami apa yang terjadi. Setelah itu dilakukan penarikan kesimpulan didukung dengan teori-teori yang sudah ada [12].

Dalam tahap reduksi data diperoleh informai wawancara lalu dikelompakkan menjadi beberapa kelompok bagian. Kemudin pada tahap display data dipaparkan data hasil wawancara, dengan data yang tidak perlu maka data tersebut dibuang. Kemudian pada tahap penarikan kesimpulan dilakukan penarikan kesimpulan berdasarkan masalah pada latar belakang dan kemudian dihubungkan dengan teori-teori yang ada dan akan diperoleh hasil penelitian.

\section{Hasil dan Pembahasan}

Pandemi Covid-19 ini merupakan sebuah masalah yang memang meresahkan di seluruh belahan dunia. Dalam menangani penyebarannya pemerintah mengeluarkan beberapa kebijakan salah satu diantaranya dalam dunia pendidikan yaitu mengehentikan aktivitas di lingkungan sekolah dan belajar mengajar dari rumah saja dengan Pembelajaran daring.

Secara umum, dalam proses pembelajaran dengan media online, haruslah memenuhi kriteria berupa tampilan yang menarik seperti gambar yang dimuat jelas, memili warna, teks yang ditampilkan atau bahasa harus jelas sehingga para peserta didik mudah memahaminya. Materi yang disajikan harus jelas dan interaktif yaitu para siswa harus ikut berpartisipasi, karakteristik materi yang disampaikan harus sesuai dengan tujuan dan target [13].

Penggunaan media google classroom dalam pembelajaran secara daring mempermudah siswa dalam proses belajar dimasa pandemi covid-19. Para siswa diberikan pelatihan serta pengajaran bagaimana menggunakan aplikasi google classroom agar proses belajar mengajar tetap lancar. 
Dalam menjalankan aplikasi google classroom siswa hanya perlu memiliki akun google mail untuk dapat masuk kedalam kelas, namun masih ada beberapa siswa yang sebelumnya belum memiliki gmail harus mendaftar akun gmail.

Berdasarkan wawancara online yang dilakukan diperoleh bahwa siswa merasa mudah dalam penggunaan aplikasi google classroom, seperti penditribusian tugas dan pengumpulan tugas memberikan kemudahan bagi para siswa, dikarenakan sistem upload file sama seperti penggunaan aplikasi facebook atau instagram yang sudah mereka tahu sebelumnya. Selain itu dalam penggunan data internet tidak banyak sehingga memudahkan dan tidak memberatkan siswa dalam proses belajar.

Hal ini didukung dari penelitian yang dilakukan harefa dan sumiyati bahwa dalam pengimplementasian pembelajaran melalui google classroom diperoleh siswa bersemangat sebanyak $39,19 \%$ dalam pembeljajaran terintegrasi diperoleh $41,98 \%$ siswa merasa senang, dalam perolehan nilai siswa merasa senang dengan pembelajaran dibantu dengan google classrom diperoleh data 47,30\%, serta siswa merasa tidak terbebani dalam tugas yang diberikan kepada mereka, diperoleh data sebesar 41,98\% [14].

Selain itu menurut hasil penelitian yang dilkukan, para siswa merasa penggunaan aplikasi google classroom kurang efektif, dikarenakan hanya file yang dapat dimasukkan oleh guru yang bersangkutan. Kurangnya pengawasan langsung menjadikan kurang efektifnya proses belajar. Didalam google classroom, guru hanya membagikan link daftar absen serta file pembelajaran tanpa ada penjelasan langsung secara virtual. Dari hal tersebut masih banyak siswa yang hanya melakukan absensi saja tanpa belajar dan membuka file yang dibagikan oleh dosen. Hal ini juga memberikan dampak kebosanan bagi para siswa. Menurut para siswa kelas XII perlunya media pembelajaran online tambahan yang dapat melakukan conference massal yang dapat menampilkan screen file/powerpoint sehingga siswa mengerti mengenai pembelajaran yang dilakukan.

Didalam sistem pembelajaran online seharusnya tidak hanya dengan membagikan file materi pembelajaran saja, namun perlunya interaksi atau penjelasan langsung dari guru kepada siswa, siswa dengan siswa agar pembelajaran online dapat dikatakan efektif [15].

Berdasarkan uraian diatas dalam penggunaan aplikasi google classroom yang diterapkan di MAS TI Canduang Sumatera Barat sebagai media pembelajaran media online dimasa Covid-19 dapat memberikan dampak positif dan negatif.

Hal ini didukung oleh penelitian yang dilakukan suhada., dkk bahwa google classroom memberikan kemudahan serta membantu dalam proses perkuliah namun untuk praktikum kurang efektif. Perlunya tambahan media lain untuk proses pembelajaran dan perkuliahan. Menurut mustakim diproleh kemudahan pembelajaran dimasa pandemi covid-19 dengan pembelajaran daring, namun para peserta didik lebih menyukai pembelajaran tatap muka [4].

Menurut Sukmawati bahwa dalam proses pembelajaran, mahasiswa aktif dengan pembelajaran melalui media online google classroom, dibuktikan bahwa mahasiswa mengumpulkan tugas sesuai dengan arahan didalam kelas google classroom. Namun mahasiswa mengeluhkan kecepatan jaringan dalam proses belajar namun mahasiswa masih dapat menggunakan fitur yang ada dalam aplikasi [8].

Sedangkan menurut Hammi penggunaan media online google classroom belum efektif dikarenakan dalam melakukan pembelajaran belum ada fitur khusus yang berhubungan dengan angka, rumus, selain itu siswa juga terkendala dengan jaringan. Selain itu siswa perlu melakukan tatap muka langsung untuk melakukan proses pembelajaran [5].

\section{Kesimpulan}

Dalam pembelajaran online, perlu diperhatikan bahwa:

1. Kegiatan yang dilakukan membutuhkan akses internet,

2. Harus ada media pembelajarannya seperti aplikasi google classrom,

3. Harus fasilitas seperti smartphone dan sejenisnya yang dapat mengakses internet,

4. perlunya pengetahuan mengenai media yang digunakan,

5. Didalam media pembelajaran online harus ada hasil evaluasi belajar

Secara umum, dalam proses pembelajaran dengan media online, haruslah memenuhi kriteria berupa tampilan yang menarik seperti gambar yang dimuat jelas, memili warna, teks yang ditampilkan atau bahasa harus jelas sehingga para peserta didik mudah memahaminya. Materi yang disajikan harus jelas dan interaktif yaitu para siswa harus ikut berpartisipasi, karakteristik materi yang disampaikan harus sesuai dengan tujuan dan target.

Dari hasil penelitian yang dilakukan bahwa penggunaan google classroom sebagai media pembelajaran online memberikan dampak postif dan negatif.

Media online sebagai media pembelajaran dimasa pendemi memberikan dampak positif berupa:

1. Memudahkan dalam proses belajar dimasa pandemi covid 19

2. Penggunaan media google classroom sangat mudah dijalankan sehingga siswa mampu dan mengerti untuk mengaksesnya 
3. Penggunaan kuota dalam penggunaan aplikasi sangat sedikit.

Selain dampk positif, terdapat dampak negatif dari penggunaan media online google classroom yaitu

1. Siswa bosan dengan pembelajaran tanpa adanya media untuk menyapaiakn secara langsung.

2. Dikarenakan kurang interaktifnya media dari google classroom sehingga tujuan pembelajaran tidak dicapai

3. Kurangnya akses internet.

Berdasarkan penelitian diatas disarankan kepada guru atau siswa untuk menambah media onlinelainnya agar proses belajar interaktif dengan media zoom, google meet, maupun media conference lainnya.

\section{Daftar Rujukan}

[1] Nizam and J. Aris, "Panduan Pembelajaran Daring Bagi Mahasiswa dengan Disabilitas Fisik," 2009.

[2] O. I. Handarini and S. S. Wulandari, "PembelajarHandarini, O. I., \& Wulandari, S. S. (2020). Pembelajaran Daring Sebagai Upaya Study From Home (SFH). Jurnal Pendidikan Administrasi Perkantoran (JPAP), 8(3), 465503.an," J. Pendidik. Adm. Perkantoran, vol. 8, no. 3, pp. 465-503, 2020.

[3] F. Firman and S. Rahayu, "Pembelajaran Online di Tengah Pandemi Covid-19," Indones. J. Educ. Sci., vol. 2, no. 2, pp. 81-89, 2020, doi: 10.31605/ijes.v2i2.659.

[4] I. Suhada et al., "Pembelajaran Daring Berbasis Google Classroom Mahasiswa Pendidikan Biologi Pada Masa Wabah Covid-19," Digit. Libr. UIN Sunan Gunung Jati, vol. 2019, pp. 19, 2020, [Online]. Available: http://digilib.uinsgd.ac.id/30584/.

[5] Z. Hammi, "Implementasi Google Classroom Pada Kelas Xi Ipa Man 2 Kudus," Skripsi, pp. 1-58, 2017, [Online]. Available: https://lib.unnes.ac.id/31039/.

[6] Nadia, SISTEM PEMBELAJARAN DARING MENGGUNAKAN MEDIA ONLINE PADA ERA COVID-19. 2020.

[7] L. D. Herliandry, Nurhasanah, M. E. Suban, and K. Heru, "Transformasi Media Pembelajaran Pada Masa Pandemi Covid-19," J. Teknol. Pendidik., vol. 22, no. 1, pp. 65-70, 2020, [Online].

Available: http://journal.unj.ac.id/unj/index.php/jtp.

[8] S. Sukmawati, "Implementasi Pemanfaatan Google Classroom Dalam Proses Pembelajaran Online di Era Industri 4 . 0," J. Kreat. Online, vol. 8, no. 1, pp. 39-46, 2020, [Online]. Available:

http://jurnal.untad.ac.id/jurnal/index.php/JKTO/a rticle/view/15680.
[9] V. D. Wicaksono and P. Rachmadyanti, "Pembelajaran Blended Learning melalui Google Classroom di Sekolah Dasar," Semin. Nas. Pendidik. PGSD UMS HDPGSDI Wil. Timur, pp. 513-521, 2016, [Online]. Available: http://hdl.handle.net/11617/9144.

[10] Mustakim, "Efektivitas Pembelajaran Daring Menggunakan Media Online Selama Pandemi Covid-19 Pada Mata Pelajaran Matematika the Effectiveness of E-Learning Using Online Media During the Covid-19 Pandemic in Mathematics," Al asma J. Islam. Educ., vol. 2, no. 1, pp. 1-12, 2020.M. S. Dr. Ismael Nurdin, Dra. Sri Hartati, Metodologi Penelitian Sosial. 2019.

[11] M. S. Dr. Ismael Nurdin, Dra. Sri Hartati, Metodologi Penelitian Sosial. 2019.

[12] H. Ahyar et al., Buku Metode Penelitian Kualitatif \& Kuantitatif, no. March. 2020.

[13] A. Marjuni and H. Harun, "Penggunaan Multimedia Online Dalam Pembelajaran," Idaarah J. Manaj. Pendidik., vol. 3, no. 2, p. 194, 2019, doi: 10.24252/idaarah.v3i2.10015.

[14] N. Harefa and S. Sumiyati, "Persepsi Siswa terhadap Google Classroom sebagai LMS pada masa Pandemi Covid-19," Sci. Educ. Appl. J., vol. 2, no. 2, p. 88, 2020, doi: 10.30736/seaj.v2i2.270.

[15] T. Belawati, Pembelajaran Online. 2019 